Original Article

\title{
Isolation and Antimicrobial Activity of $\beta$-Sitosterol-3-0- Glucoside from Lannea Kerstingii Engl. \& K. Krause (Anacardiacea)
}

\author{
Njinga N.S. ${ }^{1}$, Sule M.I. ${ }^{2}$, Pateh U.U. ${ }^{3}$, Hassan H.S. ${ }^{4}$, Abdullahi S.T. ${ }^{5}$ \& Ache R.N. ${ }^{6}$ \\ ${ }^{1,5}$ Lecturer, Department of Pharmaceutical and M edicinal Chemistry, University of Ilorin, Nigeria \\ ${ }^{2,3,4}$ Professor, Department of Pharmaceutical and M edicinal Chemistry, Ahmadu Bello University, Zaria, Nigeria \\ ${ }^{6}$ Ph.D. Student, Department of Chemistry, Faculty of Sciences, University of Yaounde I. Cameroon. \\ Correspondence \\ Njinga N. S. \\ Lecturer, Department of Pharmaceutical and Medicinal Chemistry, University of Ilorin, Nigeria. \\ E-mail : ngastanjin@yahoo.com
}

\begin{abstract}
The emergence of more and more drug resistance bacteria has led to the study of the antimicrobial activity of the compound isolated from Lannea kerstingii Engl. \& K. Krause (Anacardiacea) since the active principles of many drugs found in plants are secondary metabolites. A compound was isolated using dry vacuum liquid chromatography and eluting with $\mathrm{CHCl}_{3}{ }^{-}$EtOAc and monitored using $\mathrm{TLC}$. The glycoside was characterized using ${ }^{1} \mathrm{H} N \mathrm{NM}$ and ${ }^{13} \mathrm{C}$ NM R spectra recorded in DM SO-d6 at $400 \mathrm{M} \mathrm{Hz}$ and $125 \mathrm{M} \mathrm{Hz}$, respectively. The antimicrobial activity of the compound was determined using agar diffusion method. The minimum inhibitory concentration (MIC) and minimum bactericidal/minimum fungicidal concentration (M BC/MFC) was determined using broth dilution method. The compound isolated was found to be $\beta$-sitosterol-3-0-glucoside. The $\beta$-sitosterol-3-0-glucoside $(200 \mu \mathrm{g} / \mathrm{ml})$ was active against $\mathrm{S}$. aureus, M ethicillin Resistant Staphylococcus aureus, P. mirabilis, S. typhi, K. pneumoniae, E. coli, B. subtilis with zone of inhibition ranging from $24 \mathrm{~mm}$ to $34 \mathrm{~mm}$ and inactive against $P$. aeroginosa and Proteus vulgaris. It was also active against the fungi $\mathrm{C}$. albicans and $\mathrm{C}$. tropicalis but inactive against C. krusei. The MIC ranged from 25 to $50 \mu \mathrm{g} / \mathrm{ml}$ while the M BC/M FC ranged from 50 to $200 \mu \mathrm{g} / \mathrm{ml}$. These results show the wide spectrum antimicrobial activity of $\beta$-sitosterol-3-0-glucoside.
\end{abstract}

Keywords : sitosterol, glycoside, Lannea kerstingii, isolation

\section{Introduction}

Infectious diseases is one of the leading cause of death worldwide. In 2012 , it was responsible for $68 \%$ of all deaths globally ${ }^{[1]}$. All these are due to the emergence of multidrug resistant pathogens which contributes to the high causes of death world-wide ${ }^{[2]}$. The screening of plant extracts and plant products for antimicrobial activity has shown that plants represent a potential source of new anti-infective agents ${ }^{[3]}$.

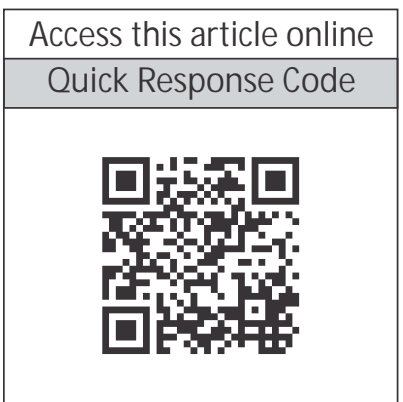

Lannea kerstingii has been reported to contain: tannins, flavonoids, alkaloids, steroids and triterpenes ${ }^{[4,5,6]}$. It is a tree with a height of $12 \mathrm{~m}$ and $40 \mathrm{~cm}$ in diameter, with a wide-spreading and relatively dense crown. The bark is smooth to slightly fissured, fissures spiral around the trunk (spiral grain), pale grey with pinkish, white-striped slash ${ }^{[7]}$. This plant is widely utilized in traditional medicine by various cultures in the world and their applications vary. In Sudan, a decoction of the back is used to treat swellings ${ }^{[8]}$. The back, leaves and bud are used for flatulence ${ }^{[9]}$, the fruits are used against rickets and scurvy ${ }^{[10]}$, the stem bark is also used in the treatment of malaria ${ }^{[11]}$, hemorrhage, diarrhoea and epilepsy $^{[4]}$. Also, in some areas in West Africa, it is prescribed against oedema, rickets, wounds, scurvy, scorbut and epilepsy ${ }^{[7]}$.

\section{Materials and method}

Plant collection and identification

The plant was collected in May, 2011 at area BZ, Ahmadu Bello University, Zaria, Kaduna State, Nigeria and identified by a botanist Mal. Umar Galla of the Department of 
Biological Science, Ahmadu Bello University, Zaria, Nigeria.

A voucher specimen (1832) was deposited in the herbarium for future references. After identification, the stem bark was dried under shad for two weeks, after which the size was reduced using mortar and pestle, filtered for homogeneity and kept away from light until further use.

\section{Extraction}

The stem bark $(580 \mathrm{~g})$ was extracted (maceration) with petroleum ether $(3 \times 1.5 \mathrm{~L})$ at room temperature. The mark was subsequently extracted with ethyl acetate $(3 \times 1.5 \mathrm{~L})$ at room temperature. Both extracts were concentrated under reduced pressure to yield a pale yellow gel petroleum ether extract $(4.32 \mathrm{~g})$ and a greenish brown solid ethyl acetate extract (10.72g).

\section{Isolation}

The ethyl acetate extract $(5 \mathrm{~g})$ was subjected to dry vacuum liquid chromatography ${ }^{[12]}$ on silica gel for TLC (M erck) using chloroform - ethyl acetate; 25:75 (210ml), 50:50, (90ml), $25: 75(4 \times 90 \mathrm{ml}), 0: 100(6 \times 90 \mathrm{ml})$ successively. This procedure afforded 12 fractions. Fraction $6(150 \mathrm{mg})$ from $\mathrm{CHCl}_{3}$ :EtOAC (75:25) contained some precipitate which was separated from the rest of the solvent by decanting and washing with chloroform. The precipitate was further subjected to chromatography on sephadex LH-20 eluting with a mixture of $\mathrm{CH}_{3} \mathrm{OH}$ and $\mathrm{CHCl}_{3}(70: 30)$ to yield $50 \mathrm{mg}$ of compound labeled C9. The Thin layer chromatography (TLC) using $\mathrm{CHCl}_{3}$-EtOAC (1:9) showed a spot with Rf value of 0.42 . The ${ }^{1} \mathrm{H}$ and ${ }^{13} \mathrm{CNM}$ R spectrum of $\mathrm{C} 9$ was recorded in DM SO-d6 at $400 \mathrm{M} \mathrm{Hzand} 125 \mathrm{M} \mathrm{Hz}$, respectively.

TLC chromatograms obtained were sprayed with a saturated solution of cetric sulphate in $65 \%$ sulphuric acid; the plates were heated at $120^{\circ} \mathrm{C}$ for 15 minutes ${ }^{[13]}$.

\section{Test organisms}

The bacteria isolates viz; Staphylococcus aureus; M ethicillin Resistant Staphylococcus aureus, Streptococcus pyogenes; Bacillus subtilis; Corynebacterium ulcereans; Escherichia coli; Proteus vulgaris; Proteus mirabilis; Pseudomonas aeruginosa; Salmonella typhi; Shigella dysenteriae; Klebsiella pneumonia and the fungi Candida albicans, Candida krusei and Candida tropicalis were gotten from Ahmadu Bello University Teaching Hospital, Zaria, Kaduna state, Nigeria. All the micro-organisms were checked for purity and maintained in slants of agar.

\section{Assay for antibacterial activity}

The test organisms were first inoculated into tubes of nutrient broth separately and incubated at $37^{\circ} \mathrm{C}$ for $18 \mathrm{~h}$. Each of the cultures was then adjusted to $0.5 \mathrm{M}$ cFarland turbidity standard and $(0.2 \mathrm{ml})$ inoculated onto Mueller Hinton agar (M HA, Oxoid) in petri plates (diameter: $15 \mathrm{~cm}$ ). A sterile cork borer was then used to make wells $(6 \mathrm{~mm}$ diameter) for the compound on each of the plates containing cultures of the different test organisms. The compound (C9) was re-dissolved in DMSO to obtain concentrations of $200 \mathrm{ug} / \mathrm{ml} . \quad 0.1 \mathrm{ml}$ of the $\mathrm{C} 9$ was then introduced into the wells using sterile Pasteur pipettes. 0.1 $\mathrm{ml}$ of DM SO only was introduced in another well to serve as negative control. Wells containing the standard antimicrobials ciprofloxacin and fluconazole $(5 \mathrm{ug} / \mathrm{ml})$ were included as positive control. The culture plates were allowed to stand on the working bench for $30 \mathrm{~min}$ for pre diffusion and were then incubated at $37^{\circ} \mathrm{C}$ for $24 \mathrm{~h}$. After 24 $h$, antibacterial activity was determined by measurement of diameter zones of inhibition (mm) (against the test organisms) around each of the extracts and the antibiotics/antifungal ${ }^{[14]}$.

\section{Minimum Inhibitory Concentration (MIC)}

The MIC of the extracts were determined for each of the test organisms at varying concentrations of $200,100,50$, $25,12.5$, and $6.25 \mathrm{mg} / \mathrm{ml}$. To obtain these concentrations, varying concentrations $(1 \mathrm{ml})$ of the extracts containing double strength of the concentrations $(200,100,50,25$, 12.5 , and $6.25 \mathrm{mg} / \mathrm{ml}$ ) in a test tube, $1 \mathrm{ml}$ of nutrient broth was added and then a loop full of the test organism previously diluted to $0.5 \mathrm{M}$ cFarland turbidity standard was introduced to the tubes. The procedure was repeated on the test organisms using the standard antibacterial ciprofloxacin and fluconazole. A tube containing nutrient broth only was seeded with the test organism to serve as 
negative control. All the tubes were then incubated at $37^{\circ} \mathrm{C}$ for $24 \mathrm{~h}$ (bacteria) and $27^{\circ} \mathrm{C}$ for $48 \mathrm{hrs}$ (fungi) and after, examined for growth by observing for turbidity ${ }^{[14]}$.

\section{Minimum Bactericidal Concentration (MBC)/ Minimum Fungicidal Concentration (M FC)}

$1 \mathrm{ml}$ bacterial/fungi culture was pipetted from the mixture obtained in the determination of M IC tubes which did not show any growth and subcultured on to MHA and incubated at $37^{\circ} \mathrm{C}$ for $24 \mathrm{hrs}$ (bacteria) and $27^{\circ} \mathrm{C}$ for 2-7days (fungi) respectively. After incubation the concentration at which there was no single colony growth of bacteria/fungi was taken as M BC/ M FC ${ }^{[15]}$.

\section{Results}

The ${ }^{1} \mathrm{H}-\mathrm{NM} \mathrm{R}$ of compound $\mathrm{C} 9$ revealed a series of peaks (singlets) between $\mathrm{dH} 0.65$ to $\mathrm{dH} 0.99$. It also showed a prominent peak at $\mathrm{dH} 3.37$, peaks between $\mathrm{dH} 2.8$ to 3.8 indicates the presence of a glucoside. Some other prominent peaks include $\mathrm{dH} 5.35(\mathrm{t})$ indicating an olefinic proton, $\mathrm{dH} 4.21$ (d) indicating an anomeric proton.

The ${ }^{13} \mathrm{C}$-NM R showed the presence of 35 carbon atoms with some prominent peaks like dc 140.9, dc 121.8, dHc 101.4, dc 77.42 which indicates the presence of olefins, and carbons linked to oxygen. Some other prominent peaks include dc 74.09, dc 70.54, dc 61.55 which also indicates carbons linked to oxygen.

The HSQC was used to connect the protons with their various carbon atoms as summarized in Table 4.3. The $\mathrm{HMBC}$ showed correlations between the protons signal at $\mathrm{dH} 4.2\left(\mathrm{HI}^{\prime}\right)$ and carbon signal dc $77.42(\mathrm{C} 3, \mathrm{~J} 3)$.

Compound C9 was found to be active against $\mathrm{S}$. aureus, M RSA, B. subtilis, E. coli, P. mirabilis, S. typhi, S. dysenteriae and $\mathrm{K}$. pneumoniae for the bacteria and $\mathrm{C}$. albicans and $\mathrm{C}$. tropicalis for the fungi. It was found to be inactive against $C$. ulcerans, P. vulgaris, P. aeruginosa and C. krusei (Table 1). The zone of inhibition ranges from $24 \mathrm{~mm}$ to $34 \mathrm{~mm}$. The compound was very active against $B$. subtilis with zone of inhibition $34 \mathrm{~mm}$ followed by $\mathrm{S}$. dysenteriae (30 mm).

The MIC of the isolated compound against the organisms ranged from $25 \mu \mathrm{g} / \mathrm{ml}$ to $50 \mu \mathrm{g} / \mathrm{ml}$ (Table 2). The MIC of C9 was $25 \mu \mathrm{g} / \mathrm{ml}$ for B. subtilis, $\mathrm{S}$. dysenteriae and $\mathrm{K}$. pneumonia. The MBC ranges from $50 \mu \mathrm{g} / \mathrm{ml}$ to $200 \mu \mathrm{g} / \mathrm{ml}$ while the MFC was $200 \mu \mathrm{g} / \mathrm{ml}$ for both C. albicans and C. tropicals (Table 2).

\section{B-Sitosteml-3-0-glucoside (1)}

${ }^{1} \mathrm{H}$ NM R (400 M Hz, DMSO-d6,): 0.65 (3H, s, M e-18) 0.80 (3H, m, Me-26), 0.79 (3H, m, M e-27) 0.85 (3H, m, M e-29) $0.96(3 \mathrm{H}, \mathrm{s}, \mathrm{Me}-19) 0.90(3 \mathrm{H}, \mathrm{d}, \mathrm{J}=7.2 \mathrm{~Hz}, \mathrm{M} \mathrm{e}-21) 3.37(\mathrm{IH}$, m, H-3), 4.24 (IH, H-I'), 5.35 (IH, m, H-6); ${ }^{13} \mathrm{CNMR}(125 \mathrm{M} \mathrm{Hz}$, DM SO-d6): ppm 12.16 (C-18) 12.28 (C-29), 20.20 (C-26), 19.10 (C-19) 19.58 (C-27), 21.06 (C-11) 23.05 (C-28), 24.33 (C-15), 25.86 (C-23), 28.27 (C-16) 31.84 (C-25), 29.15 (C-2), 31.80 (C-8), 31.84 (C-7), 33.76 (C-22), 36.68 (C-20), 37.29 (C-10), 38.75 (C-1), 39.55 (C-4), 39.34 (C-12), 42.32 (C-13), 45.59 (C-24), 50.01 (C-9), 56.69 (C-17), 55.92 (C-14), 61.55 (C-6'), 70.54 (C-4'), 74.09 (C-2'), 77.42 (C-5'), 77.42 (C-3'), 77.42 (C-3), 101.41 (C-1'), 121.83 (C-6), 140.90 (C-5).

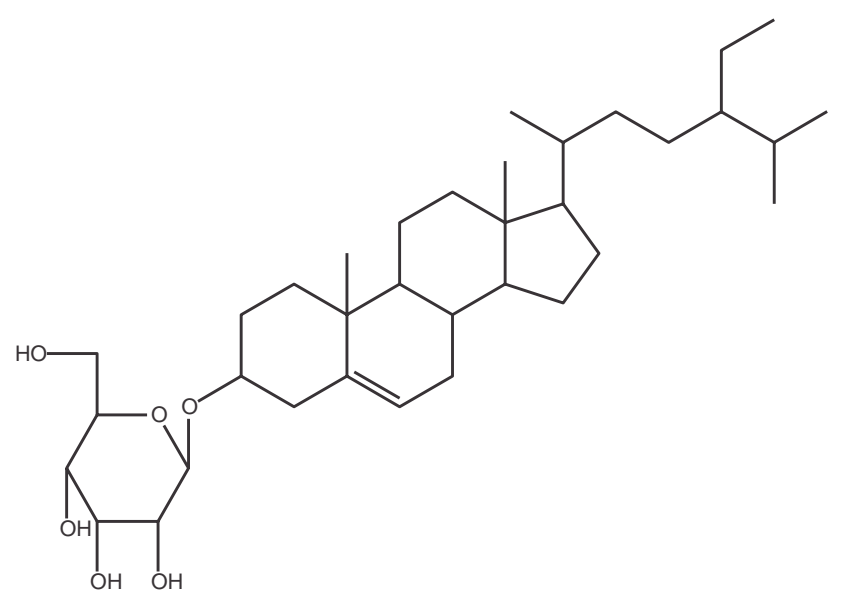

Compound C9: $\beta$-sitosterol-3-0- $\beta$-D-glucoside (1)

\section{Discussion :}

The TLC plate containing C9 showed a red-brown colour when sprayed with a solution of ceric sulphate in $65 \%$ sulphuric acid and plate heated at $120^{\circ} \mathrm{C}$ for 15 minutes ${ }^{[3]}$. This suggested the presence of a steroidal skeleton. The protonic spectrum showed six methylic signals, two singlets (M e-18 and M e-19), three doublets (M e-21, M e-26 and $\mathrm{Me}$-27), and one triplet (M e-29), whose chemical shifts obtained by a HETCOR experiment were in accordance with a $?^{5}$ sterol. The up field chemical shift at $d$ 38.75, 29.15, $77.42,39.55,121.83,31.84,21.06,39.34,24.33$ and 28.27 
Table 1: Zone of inhibition of C9 on some disease causing organisms

\begin{tabular}{|c|c|c|c|}
\hline \multirow[t]{2}{*}{ Organisms } & \multicolumn{3}{|c|}{ Zone of inhibition (mm) } \\
\hline & $\begin{array}{c}C 9 \\
(200 \mu \mathrm{g} / \mathrm{ml})\end{array}$ & $\begin{array}{c}\text { Ciprofloxacin } \\
(5 \mu \mathrm{g} / \mathrm{ml})\end{array}$ & $\begin{array}{c}\text { Fluconazole } \\
(5 \mu \mathrm{g} / \mathrm{ml})\end{array}$ \\
\hline S. aureus & 27 & 42 & \\
\hline M RSA & 24 & 0 & \\
\hline S. pyogenes & 0 & 47 & \\
\hline B. subtilis & 34 & 47 & \\
\hline C. ulcerans & 0 & 37 & \\
\hline E. coli & 27 & 34 & \\
\hline P. vulgaris & 0 & 24 & \\
\hline P. mirabilis & 24 & 30 & \\
\hline P. aeruginosa & 0 & 40 & \\
\hline S. typhi & 24 & 24 & \\
\hline S. dysenteriae & 30 & 27 & \\
\hline K. pneumoniae & 31 & 30 & \\
\hline C. albicans & 23 & & 32 \\
\hline C. krusei & 0 & & 30 \\
\hline C. tropicalis & 22 & & 29 \\
\hline
\end{tabular}

Table 2 : MIC and MBC/M FC of C9

\begin{tabular}{lccc}
\hline Organisms & $\begin{array}{c}\text { MIC } \\
(\mu \mathrm{g} / \mathrm{ml})\end{array}$ & $\begin{array}{c}\text { M BC } \\
(\mu \mathrm{g} / \mathrm{ml})\end{array}$ & $\begin{array}{c}\text { MFC } \\
(\mu \mathrm{g} / \mathrm{ml})\end{array}$ \\
\hline S. aureus & 25 & 100 & \\
M RSA & 50 & 100 & \\
B. subtilis & 25 & 50 & \\
E. coli & 50 & 100 & \\
P. mirabilis & 50 & 100 & \\
S. typhi & 50 & 200 & \\
S. dysenteriae & 25 & 100 & \\
K. pneumoniae & 25 & 50 & \\
C. albicans & 50 & & 200 \\
C. tropicalis & 50 & & 200 \\
\hline
\end{tabular}

were appropriate for the cyclohexyl and cyclopentyl carbons at positions $1,2,3,4,6,7,11,12,15$ and 16, respectively ${ }^{[16,17]}$. The chemical shift at $d 56.69$ was assigned to the carbon number 17 which was the point of linkage of the side chain to the cyclopentyl ring ${ }^{[17]}$. The olefinic proton ( $\mathrm{H}-6)$ was a multiplet at $\mathrm{d} 5.35$, confirmed also by the resonances of the ${ }^{13} \mathrm{C} N M R$ at $\mathrm{d} 122$ and $\mathrm{d} 144 \mathrm{ppm}$. In addition signals of a glucose were also present. The HM BC correlation of $\mathrm{dH} 4.2(\mathrm{H} 1)$ of the sugar with $\mathrm{C} 3(\mathrm{dc} 77.42, \mathrm{~J} 3$ ) of the steroidal nucleus indicated that the glycosidic linkage at $\mathrm{C}-3$ in the cyclopentyl ring. On the basis the ${ }^{1} \mathrm{H}$ NM R, ${ }^{13} \mathrm{C}-\mathrm{NM} \mathrm{R}$, and 2D-NM R spectral data and comparing with literature ${ }^{[18,19]}$ shows that the isolated compound $C 9$ was ß-sitosterol-3-0-glucoside.
The very low M IC and M BC of C9 on both gram positive and gram negative bacteria (Table 2 ) indicates the broad spectrum activity of $\beta$-sitosterol-3-0-glucoside its potential use as antimicrobial agent. Studies established ßsitosterol as potent antimicrobial agent at lower concentration against a wide range of bacteria including $E$. coli, Staphylococcus aureus, Klebsiella pneumonia and Pseudomonas aeruginosa ${ }^{[20]}$ which is in line with the current studies though compound C9 ( $\beta$-sitosterol-3-0- $\beta$ D-glucoside) was inactive against P. aeruginosa.

The low M IC of $\beta$-sitosterol-3-0-glucoside (Table 2 ) showed compound's activity against both Gram positive and Gram negative bacteria which are associated with different type of infections including urinary tract infections and typhoid fever (S. typhi). S. aureus which is also responsible for a wide variety of diseases including skin and soft tissue infections, pneumonia, and diabetic foot infections ${ }^{[2]]}$ can be managed using this compound. Similarly, P. aeruginosa is a common pathogen associated with burn wound infections, keratitis, and respiratory tract infections ${ }^{[22]}$. The compound also showed activity against $E$. coli which is the commonest cause of urinary tract infection and accounts for approximately $90 \%$ of first urinary tract infection in young women ${ }^{[23]}$. Thus this indicates the usefulness of this plant in the treatment of urinary tract infection, respiratory tract infections, diabetic foot infections due to its activity against the organisms causing these infections.

In view of the fact that $\mathrm{S}$. aureus is a pyogenic bacterium known to play significant role in invasive skin diseases including superficial and deep follicular lesion ${ }^{[24]}$ and that prevalence of $\mathrm{S}$. aureus resistant strains to conventional antibiotics has increased to high levels in some hospitals ${ }^{[23]}$, $\beta$-sitosterol-3-O- $\beta$-D-glucoside could serve as a remedy to such resistance since it is active against MRSA. The compound has also showed the same high level of activity against $E$. coli which is the commonest cause of urinary tract infection and accounts for approximately $90 \%$ of first urinary tract infection in young women ${ }^{[2,25]}$. Thus this result gives scientific base and credence for the claims of the therapeutic capabilities and folkloric usage of the various 
parts of Lannea kerstingii for the treatment of various ailments.

\section{Conclusion}

The compound ß-sitosterol-3-0-glucoside isolated from Lannea kerstingii showed a wide spectrum antibacterial

\section{References}

1. WHO. The top 10 causes of death. Retrieved August, 2014 from http://www.who.int/mediacentre/factsheets/fs310/en/index2.html.

2. Reddy P, Chadaga S, Noskin GA. Antibiotic considerations in the treatment of multidrug-resistant (MDR) pathogens: a case-based review.J Hosp M ed. 2009;4(6):E8-15.

3. Costa ES, Hiruma-Lima CA, Lima EO, Sucupira GC, Bertolin AO, Lolis SF et al. Antimicrobial activity of some medicinal plants of the Cerrado, Brazil. Phyotherapy Res. 2008; 22: 705-707.

4. Njinga NS, Sule MI, Pateh UU, Hassan HS, Ahmad M M, Abdullahi ST, Danja BA, Bawa B. Phytochemical and antimicrobial activity of the leaves of lannea kerstingii engl \& $\mathrm{k}$. Krause (anacadiaceae). NUJHS. 2014; 4(4):4-9.

5. Njinga NS, Sule MI, Patteh UU, Hassan HS, Usman MA, Haruna MS. Phytochemical and Antidiarrhea Activity of the M ethanolic Extract of the Stem Bark of Lannea kerstingii Engl. and K. Krause (Anacardiaceae). J. Nat. Prod. Plant Resour. 2013; 3(3):43-47

6. Koné WM, Soro D, Dro B, Yao K, Kamanzi K. Chemical Composition, Antioxidant, Antimicrobial And Acetylcholinesterase Inhibitory Properties of Lannea Barteri (Anacardiaceae). Australian Journal of Basic and Applied Sciences. 2011; 5(10):1516-1523

7. Arbonnier M. Trees, shrubs and lianas of West African dry zones. 2002; CIRAD, M argraf Publishers Gmbh, M NHN, Paris.

8. Doka IG, Yagi SM. Ethnobotanical Survey of M edicinal Plants in West Kordofan (Western Sudan). Ethno. Leaflets. 2009; 13:1409-1416.

9. Le Houerou HN. In, Les fourrages ligneux en Afrique. (Le Houerou H.H. ed), 1980; pp. 85-104, CIPEA, Addis-Abeba.. Le role des ligneux fourragers dans les zones saheliennes et soudaniennes, 1980; CIPEA, Addis-Ababa.

10. Michel A. Trees, shrubs, and lianas of West African dry zones. 2002; ACP-EU.

11. Adoum OA. Determination of toxicity effects of some savannah plants using Brine Shrimp Test (BST). Int. J. Pure App. Sci. 2008, 2:1-5.

12. Pedersen DS, Rosenbohm C. Dry Column Vacuum Chromatography. Syn. 2001:2431-2434

13. Schreiber K, Aurich O, Osske CL. Spray reagents in TLC analysis. J. Chrom. 1963; 12, 63 . and antifungal activity at concentration of $200 \mu \mathrm{g} / \mathrm{ml}$ against S. aureus, MRSA, P. mirabilis, S. typhi, K. pneumoniae, E. coli, B. subtilis and also active against the fungi $\mathrm{C}$. albicans and $\mathrm{C}$. tropicalis. This shows that the compound's ability to treat a wide range of infectious diseases.

14. Lino A, Deogracious O. The in-vitro antibacterial activity of Annona senegalensis, Securidacca longipendiculata and Steanotaenia araliacea-Ugandan M edicinl plants. Afri. Health Sci. 2006; 6(1): 31-35

15. Ajaiyeoba EO, Onocha PA, Nwozo SO, Sama W. Antimicrobial and cytotoxicity evaluation of Buchholzia coriacea stem bark. Fitoterapia. 2003; 74: 706-709.

16. Rahmana SMM, Muktaa ZA, Hossain MA. Isolation and characterization of $ß$-sitosterol-D-glycoside from petroleum extract of the leaves of Ocimum sanctum L. Asian Journal of Food and AgroIndustry. 2009, 2(01): 39-43

17. Kasal A, Budesinsky M, Griffiths WJ. In, Steroid Analysis. (M akin, H.L.J. and. Gower, DB., ed) 2006; pp. 27-156, Springer Science. Spectroscopic M ethods of Steroid Analysis. 2006; Springer Science.

18. Bilia AR, M endez J, M orelli I. Phytochemical investigations of Licania genus. Flavonoids and triterpenoids from Licania carii. Pharm. Acta Helvetiae 1996; 71:191-197

19. Wang Y, Lai D, Zhang Y, Kang A, Cao Y, Sun W. Study of steroidal saponins in Dioscorea zingiberensis C.H.Wright. J. Nat. Prod. 2009, 2:123-132

20. Sen A, Dhavan P, Shukla KK, Singh S, Tejovathi G. Analysis of IR, NM R and Antimicrobial Activity of ß-Sitosterol Isolated from Momordica charantia. Sci. Secur. J. Biotech. 2012; 1(1): 9-13

21. Shorr AF. Epidemiology and economic impact of meticillin-resistant Staphylococcus aureus: review and analysis of the literature. PharmacoEconomics. 2007; 25:751-68

22. M arquart M E, Caballero AR, Chomnawang M , Thibodeaux BA, Twining SS, Callaghan RJ. Identification of a novel secreted protease from Pseudomonas aeruginosa that causes corneal erosions. Invest Ophthalmol Vis Sci. 2005; 46:3761-3768

23. Usman $\mathrm{H}$, Abdulrahman $\mathrm{Fl}$, Ladan $\mathrm{AH}$. Phytochemical and Antimicrobial Evaluation of Tribulus terrestris L. (Zygophylaceae) Growing in Nigeria. Res. J Bio. Sci. 2007; 2(3): 244-247.

24. Adamu AY, Ahmad AA, Olonitola OS. Resistance Patterns of Staphylococcus aureus and Pseudomonas aeruginosa to some Quinolones isolated in Kano, Nigeria. SWJ. 2009, 4(1): 27-31.

Brooks GF, ButelJS, M orse SA. Jawetz, M elnick and Adelberg's M ed. Micro. (2nd Edn), M cGraw-Hill, New Delhi, India; 2002. 